\title{
Desain Simulasi Stabilitas Frekuensi Beban Hybrid PLTS Dengan PLTD
}

\author{
Irwan Syarif \\ Universitas Patria Artha, \\ Makassar-Gowa \\ irwan_syarif@patria-artha.ac.id
}

\author{
Andi Nur Putri \\ Universitas Patria Artha, \\ Makassar-Gowa \\ khaulahputri@gmail.com
}

\begin{abstract}
Abstrak - Penelitian ini bertujuan untuk mengetahui Stabilitas Frekuensi Beban Hybrid Pembangkit Listrik Tenaga Surya Fotovoltaik dan Diesel. Ada beberapa permasalahan yang dapat meningkatkan osilasi frekuensi rendah. Tingginya setting gain dan kecilnya waktu konstan pada Automatic Voltage Regulator, Terlalu banyak jaringan transmisi yang panjang sehingga kemampuan lemah (weak line). Hasil simulasi menunjukkan Daya yang dihasilkan pembangkit energi surya PV sesuai dengan besarnya intensitas radiasi matahari yang yang diterima oleh modul PV. Dengan demikian radiasi matahari $0.88 \mathrm{~kW} / \mathrm{m} 2$ akan menghasilkan daya sebesar 110,17 Watt. Besar tegangan yang dibangkitkan oleh genset sangat dipengaruhi oleh kecepatan poros dari prime mover-nya. Daya genset akan tercapai sebesar $98.08 \mathrm{~W}$ jika diberikan putaran $350 \mathrm{rad} / \mathrm{sec}$. Genset akan beroperasi bila PV dan baterai sudah tidak mampu lagi memasok permintaan daya dari beban. Dengan menggunakan metode simulasi ini didapatkan hasil penalaan parameter nilai PID yang optimal di mana, $\mathrm{Kp}=79.9999, \mathrm{Ki}=59.9998, \mathrm{Kd}$ $=9.9006$. Hal ini ditunjukkan dengan nilai settling time sebesar 5.8 detik yang merupakan nilai settling time tercepat dan juga nilai overshoot sebesar $\mathbf{- 7 . 9 3 2 e - 0 5}$ hingga 6.792e-10 pu yang merupakan nilai overshoot terkecil dari model kontroler yang lain.
\end{abstract}

Keywords - Stabilitas Frekuensi, Pembangkit PLTS Hybrid $P V$ dan Diesel

\section{PENDAHULUAN}

Kualitas tenaga listrik merupakan isu yang tidak pernah berhenti dibahas pada beberapa dekade ini. Penyedia tenaga listrik dituntut untuk mengirimkan tenaga listrik sesuai dengan standarstandar yang telah ditentukan [1]. Menurut salah satu parameter kualitas tersebut adalah harmonik. Institute of Electrical and Electronic Engineering (IEEE) standar 519-2014 mendefenisikan harmonik sebagai tegangan ataupun arus sinusoida yang mempunyai kelipatan bulat dari frekuensi dimana sistem tenaga listrik yang dirancang untuk dioperasikan $(50 \mathrm{~Hz}$ atau $60 \mathrm{~Hz})[2]$.

Industri sangat membutuhkan kualitas sistem tenaga listrik yang baik, termasuk harmonik. Kualitas daya (Power Quality) yang buruk akan menimbulkan banyak kerugian bagi suatu industri, misalnya pada motor listrik akan menyebabkan, pemanasan lebih, getaran dan suara/bising yang belebihan. Pada tarnsformator akan menyebabkan rugi inti dan rugi belitan, yang dapat menyebakan kerugian daya. Akan tetapi dilain pihak industri semen, seperti PT. Semen Bosowa Maros (PT. SBM) akan memproduksi harmonik tersebut karena penggunaan peralatan yang mempunyai impedansi tidak linear seperti penyearah (Rectifier), inverter (power converters), pengubah frekuensi (Frequency Converter/variable speed drive).

\section{TEORI DASAR}

Pembangkit listrik tenaga surya itu konsepnya sederhana, yaitu mengubah cahaya matahari menjadi energi listrik. Cahaya matahari merupakan salah satu bentuk energi dari sumber daya alam. Sel surya ini dapat menghasilkan energi listrik dalam jumlah yang tidak terbatas langsung diambil dari matahari, tanpa ada bagian yang berputar sehingga sistem sel surya bersih dan ramah lingkungan[3].

Model rangkaian sederhana dari PV-cell dapat dilihat pada gambar 1 dan atau dengan persamaan (1).

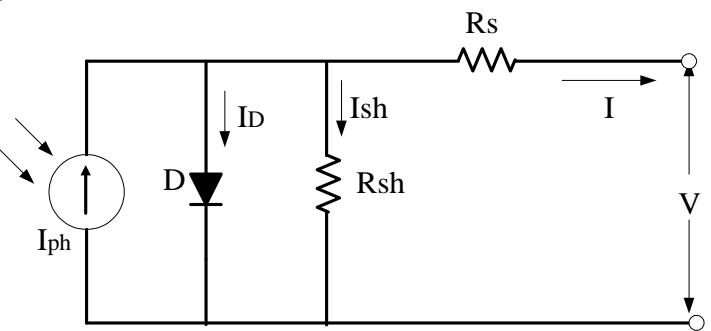

Gambar 1. Rangkaian ekivalen sederhana dari sel fotovoltaik.

Model rangkaian sederhana dari $P V$-cell dapat dilihat pada gambar 2 dan atau dengan persamaan (1). (Huan-Liang Tsai, 2008)

Pada gambar rangkaian ekivalen di atas, arus ke beban adalah:

$I=I_{p h}-I_{s}\left[\exp \left(\frac{q\left(V+I R_{S}\right)}{k T_{C} A}\right)-1\right]-\frac{V+I R_{S}}{R_{S h}}$

dimana:

$I_{p h}=$ arus photocurrent, merupakan fungsi dari radiasi dan suhu matahari.

$I_{s}=$ arus saturasi refrensi dari diode

$q=$ muatan elektron $\left(1,6 \times 10^{-19} \mathrm{C}\right)$

$V=$ Tegangan Dioda $(\mathrm{V})$

$k=$ konstanta Boltzmann $\left(1,38 \times 10^{-23} \mathrm{~J} / \mathrm{K}\right)$

$T_{c} \quad=$ Temperatur kerja sel

$A \quad=$ Faktor ideal dari Dioda 
$R_{s} \quad=$ Resistansi seri sel

$R_{s h}=$ Resistansi shunt sel

Photocurrent tergantung pada radiasi matahari dan suhu kerja sel, yang digambarkan dengan persamaan sebagai berikut [4]:

dimana:

$$
I_{p h}=\left[I_{s c}+K_{i}\left(T_{c}-T_{r e f}\right)\right] \lambda
$$

$I_{s c} \quad=$ Arus short circuit pada $25{ }^{\circ} \mathrm{C}$ dan 1 $\mathrm{kW} / \mathrm{m}^{2}$

$K_{i} \quad=$ Temperatur koefisien arus shortcircuit sel $(0.00023 \mathrm{~A} / \mathrm{K})$.

$T_{\text {ref }}=$ Temperatur referensi sel $\left(25^{\circ} \mathrm{C}\right)$.

$\lambda=$ Insolasi matahari $\left[\mathrm{kW} / \mathrm{m}^{2}\right]$

Di sisi lain, saat saturasi sel bervariasi dengan suhu sel, yang digambarkan dengan persamaan:

$$
I_{s}=I_{r s}\left(\frac{T_{c}}{T_{\text {ref }}}\right)^{3} \exp \left[\frac{q E_{g}\left(\frac{1}{T_{r e f}}-\frac{1}{T_{c}}\right)}{k A}\right]
$$

Dimana:

$$
\begin{aligned}
I_{r s}= & \text { Arus saturasi sel pada temperatur } \\
& \text { refrensi dan radiasi matahari } \\
E_{g}= & \text { energi bang-gap dari semikonduktor } \\
& \text { pada sel }(\text { Silocon }=1.11 \mathrm{eV}) . \\
A= & \text { Konstanta dari jenis produk } \\
& \text { Photovoltaik }(\text { Si-mono }=1.2) .
\end{aligned}
$$

Model Modul Fotovoltaik Karena sel PV hanya menghasilkan kurang dari $2 \mathrm{~W}$ dan sekitar $0.5 \mathrm{~V}$ maka sel-sel harus terhubung dalam konfigurasi seriparalel pada modul untuk menghasilkan daya yang cukup tinggi. Sebuah modul PV adalah beberapa sel PV yang dihubungkan secara seri dan paralel untuk menghasilkan arus dan tegangan yang diperlukan. Rangkaian ekivalen pada modul PV diatur secara seri $N s$ dan paralel $N p$ yang dapat ditunjukkan pada Gambar 2 sehingga persamaan arus dan tegangan dari modul PV adalah [5],

$$
I=N_{p} I_{p h}-N_{p} I_{S}\left[\exp \left(\frac{q\left(\frac{V}{N_{S}}+\frac{I R_{S}}{N_{p}}\right)}{k T_{c} A}\right)-1\right]-\frac{\frac{N_{p} V}{N_{S}}+I R_{S}}{R_{S h}}
$$

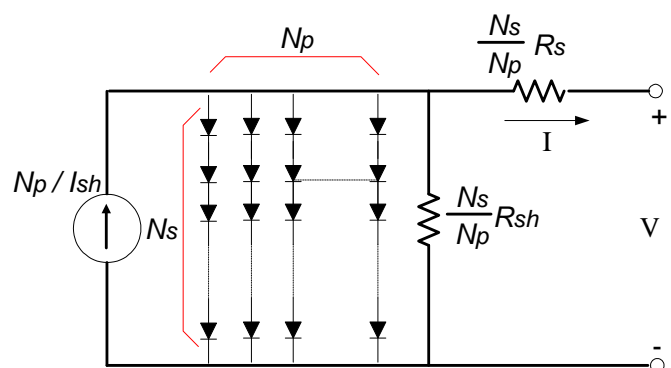

Gambar 2. Model rangkaian ekivalen seri-paralel sel fotovoltaik.

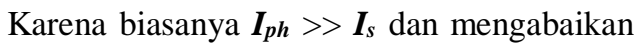
arus bocor ke tanah dibawah nol, sehingga arus shortcircuit ( $\left.\boldsymbol{I}_{s}\right)$ sama dengan photocurrent $\left(\boldsymbol{I}_{p h}\right)$, yaitu :

$$
I_{p h}=I_{s c}
$$

Di sisi lain, parameter $\boldsymbol{V}_{\boldsymbol{o c}}$ diperoleh dengan asumsi bahwa arus output adalah nol. Mengingat bahwa teganan open-circuit PV ( $\left.\boldsymbol{V}_{\boldsymbol{o c}}\right)$ pada suhu referensi dan mengabaikan kebocoran arus shunt, arus saturasi balik saat ini pada suhu referensi dapat diperoleh sebagai:

$$
I_{r s}=\frac{I_{S C}}{\left[\exp \left(\frac{q V_{o c}}{N_{S} k T_{C} A}\right)-1\right]}
$$

Selain itu, daya maksimum dapat dinyatakan sebagai:

$$
P_{\text {max }}=V_{\text {max }} I_{\text {max }}=\gamma V_{o c} I_{s c}
$$

Dimana $\boldsymbol{V}_{\max }$ dan $\boldsymbol{I}_{\max }$ adalah terminal tegangan dan arus keluaran dari modul PV pada titik daya maksimum (MPP), dan $\boldsymbol{\gamma}$ adalah faktor sel yang merupakan ukuran kualitas sel.

Bentuk kurva karakteristik modul fotovoltaik ditunjukkan pada gambar 3 .

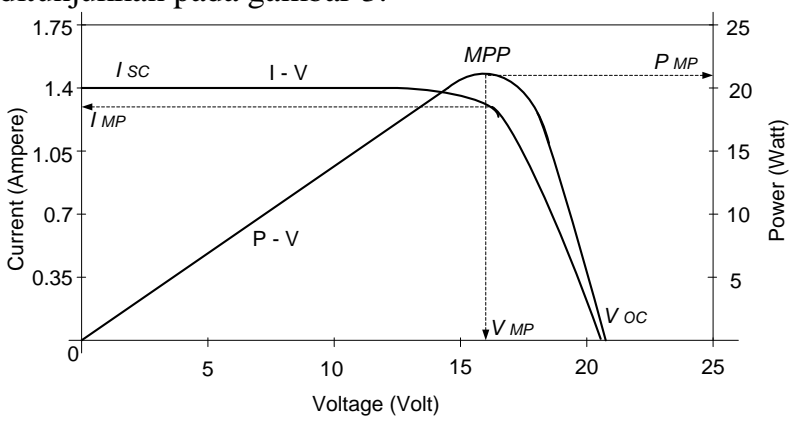

Gambar 3. Kurva Karakteristik I - V dan P - V modul PV.

Kurva di atas menggambarkan hubungan antara arus dan tegangan serta daya dengan tegangan yang dihasilkan oleh suatu modul fotovoltaik. Variasi dari kurva ini tergantung dari prosentase radiasi sinar matahari yang mengenai panel sel surya.

Rangkaian ekivalen baterai dapat diperlihatkan pada gambar 4, dimana terdiri dari sebuah sumber tegangan dengan hambatan yang disusun seri.

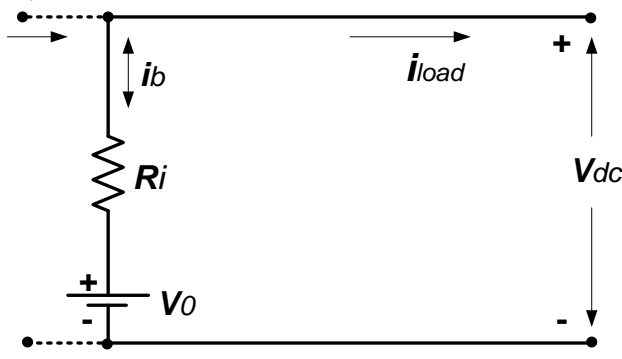

Gambar 4. Rangkaian ekivalen baterai Lead-Acid.

Pada gambar di atas, tegangan pada terminal baterai $\left(V_{d c}\right)$ dinyatakan dalam persamaan:

$V_{d c}=V_{0}-R_{i} i_{b}(t)$

Daya yang diambil dari baterai dapat dinyatakan sebagai:

$$
P_{b b}(t)=V_{d c} i_{b}(t)
$$

Energi yang masih tersimpan pada baterai setelah beban menarik daya dari baterai juga dapat dinyatakan sebagai:

$$
e_{b b}=e_{b b_{\text {_init }}}(t)-\int P_{b b}(t) d t
$$


Baterai dapat berukuran sedemikian rupa sehingga mampu menyimpan energi yang cukup dari sumber daya energi terbarukan ketika ada banyak pasokan, agar dapat menyediakan permintaan selama periode matahari yang rendah atau tidak ada sama sekali.

Ukuran dan kapasitas baterai tergantung pada konsumsi energi harian (kWh/hari). Ukuran dari baterai dapat dirumuskan sebagai:

$$
B C=\frac{E_{\text {daily_load_deman }}}{\eta_{b}} \frac{D O A}{D O D} \quad[W h]
$$

dimana :

$$
\begin{array}{ll}
\boldsymbol{E}_{\text {daili_load_demand }}= & \text { Permintaan energi total harian } \\
& {[\mathrm{Wh} / \text { hari] }} \\
= & \text { Depth of Discharge (Tinggi debit } \\
& \text { dari baterai) [70\%] } \\
= & \text { Days of Autonomous (Jumlah hari } \\
& \text { tanpa sinar) [diasumsikan 1] } \\
\text { DOA } & \text { Efisiensi baterai [85 \%] }
\end{array}
$$

Tegangan baterai sangat tergantung pada keadaan baterai apakah terisi penuh atau tidak.

\section{METODOLOGI PENELITIAN}

Energi listrik merupakan sumber energi yang paling banyak dimanfaatkan manusia untuk menjalankan dan mendukung semua aktifitasnya, baik konsumsi rumah tangga maupun penggunaan dalam industri dan dunia usaha lainnya. Penggunaan energi listrik akan terus meningkat seiring dengan semakin meningkatnya kualitas hidup dan peradaban manusia, sehingga tuntutan untuk menjamin ketersediaan energi listrik menjadi sebuah keharusan.

Oleh karena itu untuk mengatasi kelangkaan energi listrik disuatu daerah kepulawan yang terpencil yang belum dijangkau dengan listrik, maka perlu diadakan suatu terobosan pemanfaatan energi listrik dari pembangkit listrik hibrid yang optimal.

\section{HASIL DAN PEMBAHASAN}

Dalam penelitian ini, model sistem pembangkit tenaga hibrid terdiri dari sub sistem PV, Genset, baterai dan sub sistem kontrollernya. Simulasi pada penelitian ini dilakukan dengan perangkat lunak Matlab Simulink. Untuk melihat respon dari setiap sub sistem, maka akan disimulasikan setiap sub-sub sistem ini. Parameter yang dipilih untuk pemodelan sesuai dengan modul yang ada di Lokasi Penelitan

Berdasarkan data setelah di masukkan dalam simulasi Matlab dengan Rs sebesar $0.0001 \Omega$ dan Rsh sebesar $1000 \Omega$, maka karakteristik I - V dan P - V dari modul PV dapat dilihat pada gambar berikut.

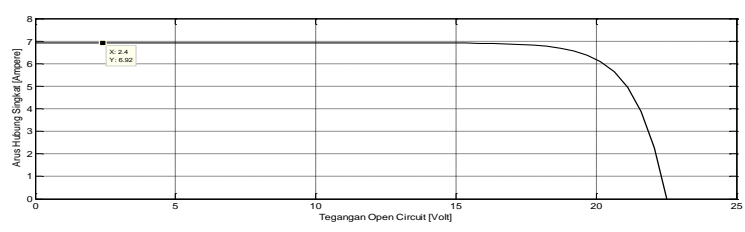

(a)

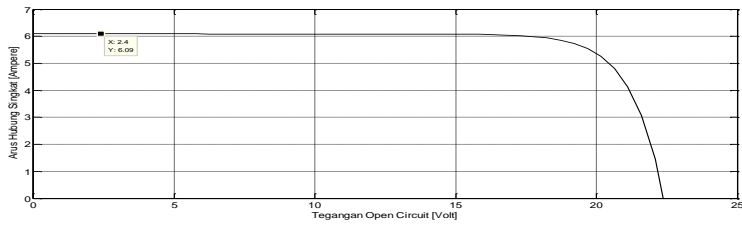

(b)

Gambar 5. Kurva karakteristik I - V modul PV, (a) pada temperatur $25 \mathrm{oC}$ dan radiasi matahari sebesar 1

$\mathrm{kW} / \mathrm{m} 2$, (b) pada temperatur $25 \mathrm{oC}$ dan radiasi matahari sebesar $0.88 \mathrm{~kW} / \mathrm{m} 2$

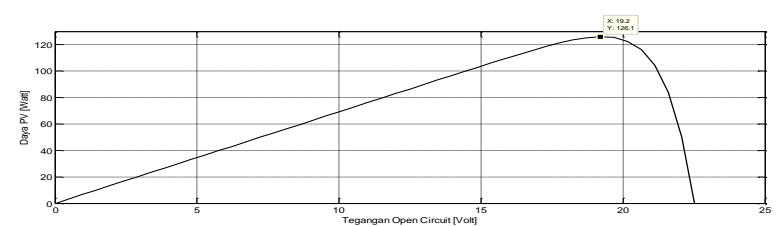

(a)

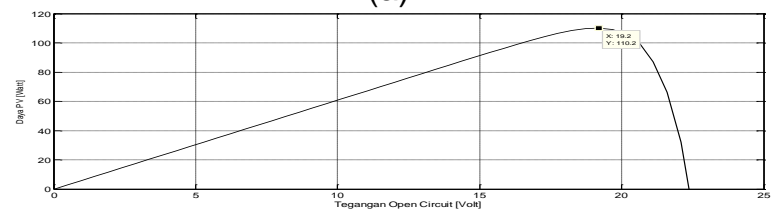

(b)

Gambar 6. Kurva karakteristik P - V modul PV,

(a) pada temperatur $25 \mathrm{oC}$ dan radiasi matahari sebesar $1 \mathrm{~kW} / \mathrm{m} 2$, (b) pada temperatur $25 \mathrm{oC}$ dan radiasi matahari sebesar $0.88 \mathrm{~kW} / \mathrm{m} 2$

Berdasarkan data, setelah di masukkan dalam simulasi Matlab Simulink dan kecepatan mesin disetel dengan kecepatan konstan $350 \mathrm{rad} / \mathrm{sec}$ kemudian kecepatan $150 \mathrm{rad} / \mathrm{sec}$, maka karakteristik tegangan, arus dan daya dari genset dapat dilihat pada gambar berikut.

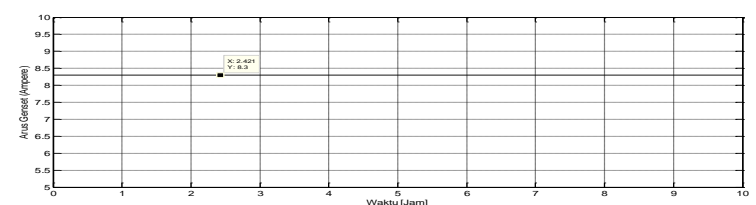

(a)

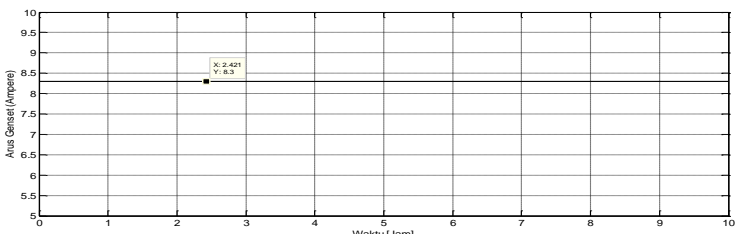

(b)

Gambar 7. Profil Arus genset, (a) pada kecepatan 350 $\mathrm{rad} / \mathrm{sec}$, (b) kecepatan $150 \mathrm{rad} / \mathrm{sec}$

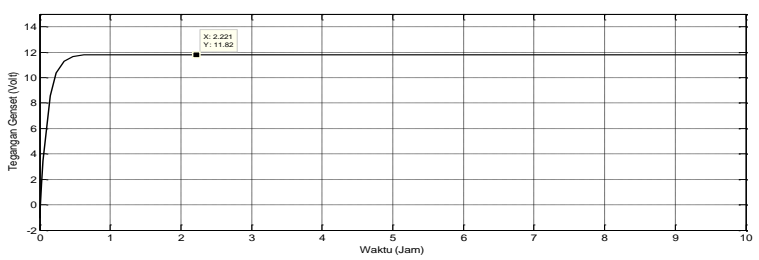

(a) 


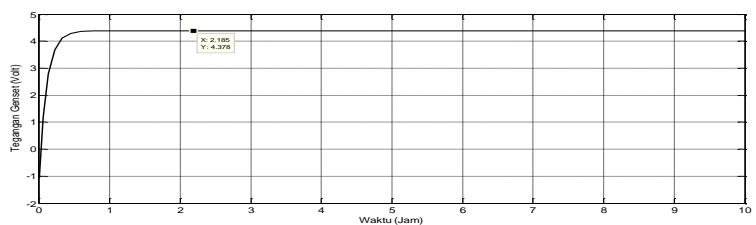

(b)

Gambar 8. Profil Tegangan yang dibangkitkan oleh genset, (a) pada kecepatan 350 $\mathrm{rad} / \mathrm{sec}$, (b) kecepatan $150 \mathrm{rad} / \mathrm{sec}$

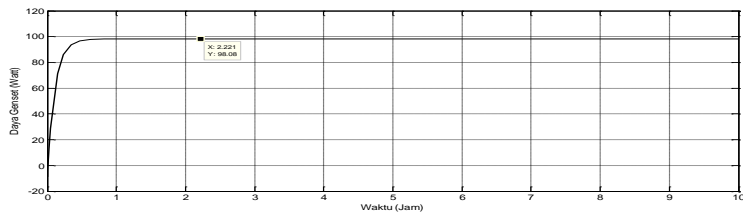

(a)

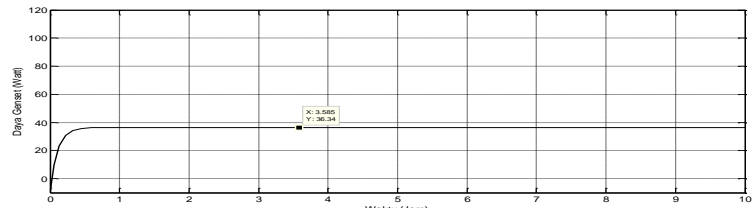

(b)

Gambar 9. Profil Daya yang dibangkitkan oleh genset, (a) pada kecepatan $350 \mathrm{rad} / \mathrm{sec}$, (b) kecepatan $150 \mathrm{rad} / \mathrm{sec}$.

Sumber energi terbarukan yang digunakan pada penelitian ini adalah energi surya dimana radiasi matahari merupakan fungsi dari daya yang dibangkitkan oleh PV. Untuk melihat perubahan daya yang dibangkitkan PV setiap jamnya dalam waktu tiga hari atau 72 jam, maka radiasi matahari perjam akan merupakan input dari PV. Pada tabel 1 akan ditampilkan radiasi matahari perjam dalam waktu tiga hari atau 72 jam untuk daerah Makassar.

Tabel 1. Radiasi matahari perjam untuk kota Makassar selama tiga hari.

\begin{tabular}{|c|c|c|c|c|c|}
\hline \multicolumn{2}{|c|}{ Hari I } & \multicolumn{2}{|c|}{ Hari II } & \multicolumn{2}{|c|}{ Hari III } \\
\hline $\begin{array}{l}\text { Waktu } \\
\text { ( Jam ) }\end{array}$ & $\stackrel{\lambda}{\lambda\left(k W / m^{2}\right)}$ & $\begin{array}{l}\text { Waktu } \\
\text { (Jam) }\end{array}$ & $\stackrel{\lambda}{\lambda}$ & $\begin{array}{l}\text { Waktu } \\
\text { ( Jam ) }\end{array}$ & $\stackrel{\lambda}{\lambda}$ \\
\hline 00.00 & 0 & 25.00 & 0 & 49.00 & 0 \\
\hline 01.00 & 0 & 26.00 & 0 & 50.00 & 0 \\
\hline 02.00 & 0 & 27.00 & 0 & 51.00 & 0 \\
\hline 03.00 & 0 & 28.00 & 0 & 52.00 & 0 \\
\hline 04.00 & 0 & 29.00 & 0 & 53.00 & 0 \\
\hline 05.00 & 0 & 30.00 & 0 & 54.00 & 0 \\
\hline 06.00 & 0 & 31.00 & 0 & 55.00 & 0 \\
\hline 07.00 & 0 & 32.00 & 0 & 56.00 & 0 \\
\hline 08.00 & 0.70 & 33.00 & 0.70 & 57.00 & 0.70 \\
\hline 09.00 & 0.72 & 34.00 & 0.71 & 58.00 & 0.72 \\
\hline 10.00 & 0.76 & 35.00 & 0.75 & 59.00 & 0.76 \\
\hline 11.00 & 0.79 & 36.00 & 0.77 & 60.00 & 0.80 \\
\hline 12.00 & 0.84 & 37.00 & 0.83 & 61.00 & 0.85 \\
\hline 13.00 & 0.88 & 38.00 & 0.86 & 62.00 & 0.89 \\
\hline 14.00 & 0.84 & 39.00 & 0.84 & 63.00 & 0.84 \\
\hline 15.00 & 0.72 & 40.00 & 0.71 & 64.00 & 0.72 \\
\hline 16.00 & 0.71 & 41.00 & 0.70 & 65.00 & 0.71 \\
\hline 17.00 & 0 & 42.00 & 0 & 66.00 & 0 \\
\hline 18.00 & 0 & 43.00 & 0 & 67.00 & 0 \\
\hline 19.00 & 0 & 44.00 & 0 & 68.00 & 0 \\
\hline 20.00 & 0 & 45.00 & 0 & 69.00 & 0 \\
\hline 21.00 & 0 & 46.00 & 0 & 70.00 & 0 \\
\hline 22.00 & 0 & 47.00 & 0 & 71.00 & 0 \\
\hline 23.00 & 0 & 48.00 & 0 & 72.00 & 0 \\
\hline 24.00 & 0 & & & & \\
\hline
\end{tabular}

Berdasarkan tabel 1 di atas, terlihat bahwa pada waktu 00.00 sampai 07.00 dan waktu 17.00 sampai 32.00, waktu 42.00 sampai 56.00 dan 66.00 sampai 72.00 , terlihat bahwa nilai radiasi matahari dianggap nol karena pada kondisi itu radiasi matahari tidak efektif lagi untuk membangkitkan daya pada PV. Grafik Intensitas radiasi matahari selama tiga hari dapat dilihat pada gambar.

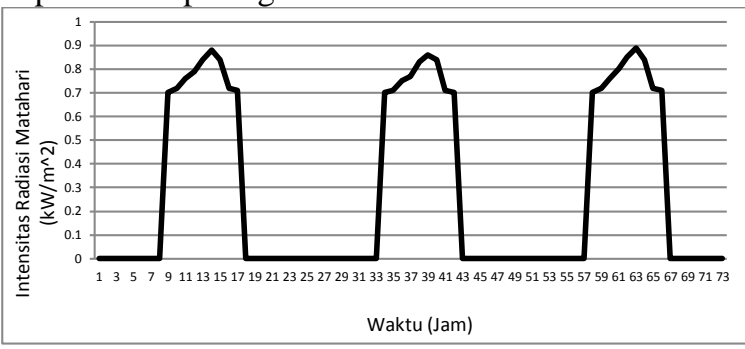

Gambar 10. Grafik intensitas radiasi matahari perjam selama 72 jam (selama tiga hari)

Berdasarakan data-data yang telah diverifikasi berdasarkan data sheet alat-alat seperti PV, genset, baterai maupun data radiasi matahari dan temperatur refrensi, maka setelah simulasi hibrid ini dijalankan akan menghasilkan data (Lampiran 2.1) dan grafik seperti pada gambar.

Selain mensimulasikan hibrid antara PV, genset dan baterai dengan data sheet yang ada dengan kapasitas baterai $2500 \mathrm{Ah}$, juga akan disimulasikan hibrid antara PV, genset dan Baterai dengan kapasitas 2500 Ah dan grafik hasil simulasiya.

Hasil Simulasi dengan Kapasitas penyimpanan Baterai 40 Ah

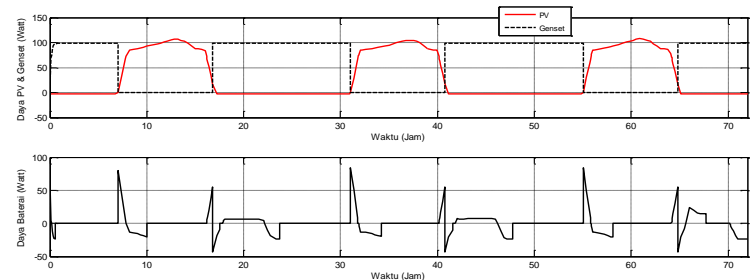

Gambar 11. (a) Profil Daya PV dan Genset, (b) Profil Daya Baterai yang di pasok ke beban pada kapasitas baterai $40 \mathrm{Ah}$.

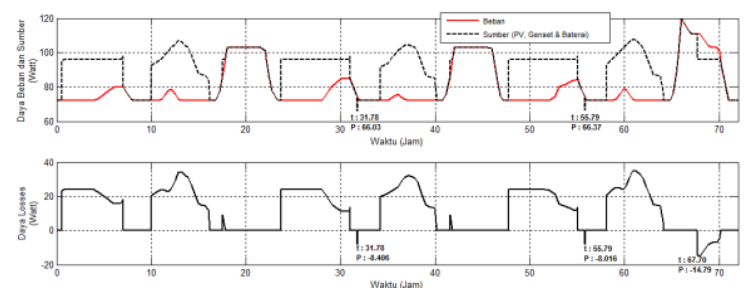

Gambar 12. (a) Profil Daya Beban dan Daya Sumber (PV, Genset dan Baterai) , (b) Profil rugi-rugi Daya pada kapasitas baterai $40 \mathrm{Ah}$. 


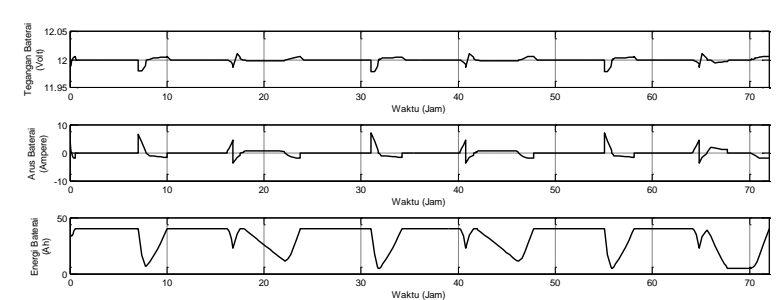

Gambar 13. (a) Profil Tegangan Baterai, (b) Profil Arus Baterai dan (c) Profil Energi Baterai pada kapasitas baterai $40 \mathrm{Ah}$.

\section{Hasil Simulasi dengan Kapasitas penyimpanan Baterai $80 \mathrm{Ah}$}
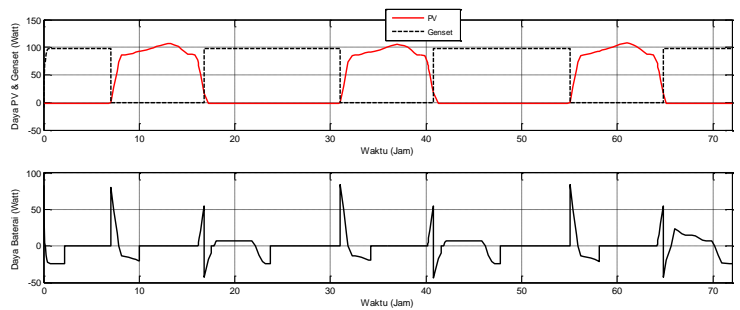

Gambar 14. (a) Profil Daya PV dan Genset, (b) Profil Daya Baterai yang di pasok ke beban pada kapasitas baterai $80 \mathrm{Ah}$

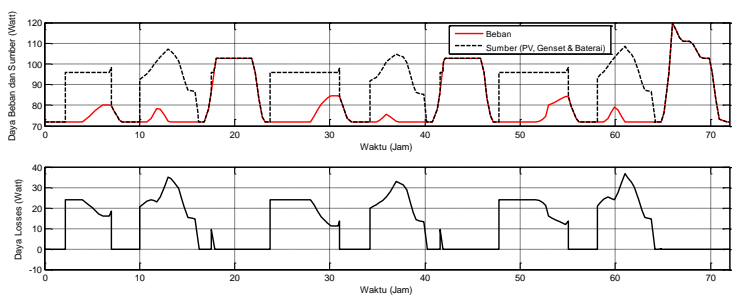

Gambar 15. (a) Profil Daya Beban dan Daya Sumber (PV, Genset dan Baterai), (b) Profil rugi-rugi Daya pada kapasitas baterai $80 \mathrm{Ah}$.

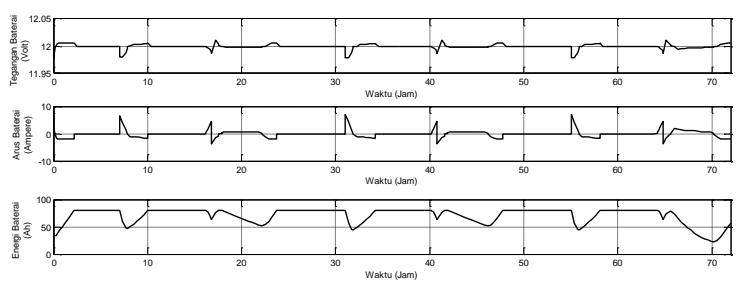

Gambar 16. Profil Tegangan Baterai, (b) Profil Arus Baterai, (c) Profil Energi Baterai pada kapasitas baterai $80 \mathrm{Ah}$.

\section{Simulasi Modul Fotovoltaik (PV-module)}

Berdasarkan grafik karakteristik I - V dan P - V hasil simulasi (gambar 1 dan 2) dapat terlihat bahwa dengan temperatur $25 \mathrm{oC}$ dan radiasi matahari sebesar $1 \mathrm{~kW} / \mathrm{m} 2$ akan menghasilkan arus hubung singkat Isc sebesar sebesar 6.92 A dan daya maksimum Ppv sebesar 126.1 Watt pada tegangan open circuit Voc sebesar 22.53. Sedangkan pada temperatur yang sama dengan radiasi matahari sebesar $0.88 \mathrm{~kW} / \mathrm{m} 2$ akan menghasilkan arus hubung singkat Isc sebesar sebesar 6.09 A dan Ppv maksimum sebesar 110,17 Watt pada tegangan open circuit Voc sebesar 22.53. Jadi semakin besar radiasi matahari yang mengenai sel PV maka semakin besar daya yang dibangkitkan.

\section{Simulasi Genset}

Berdasarkan hasil simulasi yang dilakukan (gambar 4, 5 dan 6) dapat terlihat bahwa bila genset diberikan putaran sebesar $350 \mathrm{rad} / \mathrm{sec}$ akan menghasilkan tegangan Vdg sebesar $11.82 \mathrm{~V}$, arus Idg sebesar 8,3A dan Daya Pdg sebesar 98.08W. Sedangkan pada putaran $150 \mathrm{rad} / \mathrm{sec}$ akan menghasilkan tegangan $\mathrm{Vdg}$ sebesar $4.378 \mathrm{~V}$, arus Idg sebesar 8.3A dan Daya Pdg sebesar 36.34W. Jadi semakin besar putaran pada genset maka semakin besar tegangan yang dibangkitkan sehingga dapat membangkitkan daya lebih besar pula.

\section{Simulasi Hibrid}

Berdasarkan hasil simulasi hibrid yang telah dilakukan dan mengamati gambar 6 terlihat bahwa pada saat PV telah membangkitkan daya, maka genset akan berhenti beroperasi (off). Ketika terjadi peralihan pasokan dari genset ke PV akan terjadi kekurangan pasokan daya dari sumber pembangkit, tetapi hal ini akan di layani oleh baterai karena saat itu baterai telah mampu melayani untuk sementara ke beban. Jadi ini terlihat bahwa genset akan berhenti beroperasi jika baterai dan PV mampu untuk melayani beban.

Pada gambar 7 (menggunakan baterai dengan kapasitas $40 \mathrm{Ah}$ ) terlihat bahwa pada waktu 31.78 daya beban lebih besar dari pada daya sumber. Dengan demikian sumber kekurangan daya sebesar 8,406 Watt. Hal ini juga terjadi pada saat waktu menunjukkan jam ke 55.79, dimana sumber kekurangan pasokan sebesar 8,016 Watt. Pada jam ke 67.70 sampai jam ke 70.04 juga terjadi kekurangan pasokan dengan nilai maksimal 14,79 Watt. Berbeda halnya pada pada gambar 9 dimana pada simulasi ini menggunakan baterai dengan kapasitas 80 Ah. Pada gambar ini terlihat bahwa selama 72 jam tidak ada kekurangan pasokan daya dari sumber pembangkit dan baterai.

Pada gambar 5 dan 7 terlihat bahwa rugi-rugi daya akan terjadi jika genset beroperasi tetapi permintaan daya beban lebih kecil tetapi juga tidak mampu diatasi oleh baterai dan PV. Rugi-rugi daya juga akan terjadi pada saat PV membangkitkan daya maksimum pada saat siang hari tetapi permintaan beban lebih kecil dan baterai telah terisi penuh.

Proses charging/discharging baterai dapat dilihat pada gambar 6 dan 9, dimana bila terjadi proses charging ditunjukkan dengan kenaikan tegangan dan energi baterai dan nilai arus baterai negatif. Begitupun sebaliknya, bila terjadi proses discharging ditunjukkan dengan menurunnya tegangan dan energi baterai dan nilai arus baterai positif.

\section{KESIMPULAN}

Hasil simulasi menunjukkan Daya yang dihasilkan pembangkit energi surya PV sesuai dengan besarnya intensitas radiasi matahari yang yang 
diterima oleh modul PV. Dengan demikian radiasi matahari $0.88 \mathrm{~kW} / \mathrm{m} 2$ akan menghasilkan daya sebesar 110,17 Watt. Besar tegangan yang dibangkitkan oleh genset sangat dipengaruhi oleh kecepatan poros dari prime mover-nya. Daya genset akan tercapai sebesar 98.08W jika diberikan putaran $350 \mathrm{rad} / \mathrm{sec}$. Genset akan beroperasi bila PV dan baterai sudah tidak mampu lagi memasok permintaan daya dari beban. Dengan menggunakan metode simulasi ini didapatkan hasil penalaan parameter nilai PID yang optimal di mana, $\mathrm{Kp}=79.9999, \mathrm{Ki}=59.9998, \mathrm{Kd}$ $=9.9006$. Hal ini ditunjukkan dengan nilai settling time sebesar 5.8 detik yang merupakan nilai settling time tercepat dan juga nilai overshoot sebesar -7.932e-05 hingga $6.792 \mathrm{e}-10$ pu yang merupakan nilai overshoot terkecil dari model kontroler yang lain.

\section{UCAPAN TERIMA KASIH}

Pada kesempatan penulis mengucapkan teri makasih kepada Kementrian Ristek Dikti yang telah memberi bantuan dana dengan nomor kontrak 113/SP2H/LTDRPM/2018 dan kepala LPPM Universitas Patria Artha yang telah meberikan arahan dan bantuan selama proses penelitian berlangsung.

\section{DAFTAR PUSTAKA}

[1] Z. Abidin, "Pengaturan Frekuensi Beban Hibrid Turbin Angin Diesel Dengan Menggunakan Algoritma Genetika," J. Tek. ISSN, vol. 2085, p. 0859, 2010.

[2] M. J. Yerkohok, "Analisa Hybrid Sistem PvBatteray-Diesel Untuk Daerah Terpencil Di Papua Barat Menggunakan Homer (Studi Kasus: Kampung Kamat, Kabupaten Maybrat)," PROtek J. Ilm. Tek. Elektro, vol. 5, no. 2, pp. 98105, 2018.

[3] N. Farokhnia, S. H. Fathi, N. Yousefpoor, and M. K. Bakhshizadeh, "Minimisation of total harmonic distortion in a cascaded multilevel inverter by regulating voltages of dc sources," IET Power Electron., vol. 5, no. 1, pp. 106-114, 2012.

[4] E. Dermawan, A. Firmanto, S. N. Ambo, E. Diniardi, and A. I. Ramadhan, "Desain Frekuensi Kontrol pada Hybrid Wind-diesel dengan PidParticle Swarm Optimization (Pso)," Pros. Semnastek, 2016.

[5] D. Dapis, "Desain Frekuensi Kontrol pada Hibrid Wind-Diesel dengan PID-Diferensial Evolusi," ReTII, 2015.

[6] M. A. H. Sirad, "Optimasi Sistem Pembangkit Listrik Tenaga Angin Dan Pembangkit Listrik Tenaga Diesel Berbasis Fuzzy Logic," PROtek J. Ilm. Tek. Elektro, vol. 6, no. 2, pp. 102-106, 2019. 